Additional educational resources for healthcare professionals

Cooper DS. Hyperthyroidism. Lancet 2003;362:459-68 Abraham P, Avenell A, Watson WA, Park CM, Bevan JS. Antithyroid drug regimen for treating Graves' hyperthyroidism. Cochrane Database Syst Rev 2005;(4):CD003420

Cooper DS. Antithyroid drugs. $N$ Engl J Med 2005;352:905-17

Pearce EN, Farwell AP, Braverman LE. Thyroiditis. $N$ Engl J Med 2003;348:2646-55

Cawood T, Moriarty P, O'Shea D. Recent developments in thyroid eye disease. BMJ 2004;329:385-90

\section{Information resources for patients}

American Thyroid Association (www.thyroid.org)Offers FAQs, a list of patient oriented books, lists of patient support organisations, and web brochures Thyroid Foundation of America (www.allthyroid.org)Offers information about thyroid disease and treatment as well as articles for patients

British Thyroid Foundation (www.btf-thyroid.org) Provides some general information about the thyroid as well as numerous UK links

Thyroid Foundation of Canada (www.thyroid.ca)Offers thyroid health guides in English and French

National Graves' Disease Foundation

(www.ngdf.org)-A US-based patient support group.

The web site includes a recommended reading list and downloadable brochures

atrial fibrillation and may decrease the risk of low bone density in postmenopausal women. ${ }^{24}{ }^{25}$ Once the decision has been made to treat subclinical hyperthyroidism, the goal of therapy is to normalise serum TSH values, preferably by using small doses of thionamides or, less advisably, definitive therapy with ${ }^{131} \mathrm{I}$.

\section{When should general practitioners refer?}

Because patients with thyrotoxicosis usually present to general practitioners rather than to specialists, it is essential for all medical practitioners to recognise typical signs and symptoms and to know how to initiate a diagnostic work-up. In most cases, once thyrotoxicosis has been detected, patients should be referred to an endocrinologist for management. ${ }^{\mathrm{w} 13}$ Coordination of care between general practitioners and endocrinologists is essential in order to provide optimal and cost effective care for patients with thyrotoxicosis.

\section{Conclusions}

Thyrotoxicosis can be readily diagnosed on the basis of serum thyroid function tests in patients with typical signs or symptoms. Several effective forms of therapy for thyrotoxicosis exist, all of which have advantages and disadvantages. The choice of treatment depends on the cause and severity of the thyrotoxicosis, as well as on patients' preferences. Box 2 gives information on unanswered research questions and ongoing clinical trials.

Competing interests: None declared.

1 Cooper DS. Hyperthyroidism. Lancet 2003;362:459-68.

2 Streetman DD, Khanderia U. Diagnosis and treatment of Graves' disease Ann Pharmacother 2003:37:1100-9.

3 Pearce EN, Farwell A, Braverman LE. Current concepts: thyroiditis. N Engl J Med 2003;348:2646-55.
4 Muller AF, Drexhage HA, Berghout A. Postpartum thyroiditis and autoimmune thyroiditis in women of childbearing age: Recent insights and consequences for antenatal and postnatal care. Endocr Rev and consequences

5 Cooper DS. Antithyroid drugs. N Engl J Med 2005;352:905-17.

6 Weetman AP, McGregor AM, Hall R. Evidence for an effect of antithyroid drugs on the natural history of Graves' disease. Clin Endocrinol (Oxf) 1984;21:163-72.

7 He CT, Hsieh AT, Pei D, Hung YJ, Wu LY, Yang TC, et al. Comparison of single daily dose methimazole and propylthiouracil in the treatment of Graves' hyperthyroidism. Clin Endocrinol (Oxf) 2004;60:676-81.

8 Abraham P, Avenell A, Watson WA, Park CM, Bevan JS. Antithyroid drug regimen for treating Graves' hyperthyroidism. Cochrane Database Syst Rev 2005;(4):CD003420.

9 Cooper DS, Goldminz D, Levin AA, Ladenson PW, Daniels GH, Molitch $\mathrm{ME}$, et al. Agranulocytosis associated with antithyroid drugs. Effects of patient age and drug dose. Ann Intern Med 1983;98:26-9.

10 Woeber KA. Methimazole-induced hepatotoxicity. Endocr Pract 2002;8:222-4

11 Noh JY, Asari T, Hamada N, Makino F, Ishikawa N, Abe Y, et al. Frequency of appearance of myeloperoxidase-antineutrophil cytoplasmic antibody (MPO-ANCA) in Graves' disease patients treated with propylthiouracil and the relationship between MPO-ANCA and clinical manifestations. Clin Endocrinol (Oxf) 2001;54:651-4.

12 Mortimer RH, Cannell GR, Addison RS, Johnson LP, Roberts MS, Bernus I. Methimazole and propylthiouracil equally cross the perfused human I. Methimazole and propylthiouracil equally cross the perfused
term placental lobule. J Clin Endocrinol Metab 1997;82:3099-102.

13 Momotani N, Noh JY, Ishikawa N, Ito K. Effects of propylthiouracil and methimazole on fetal thyroid status in mothers with Graves hyperthyroidism.J Clin Endocrinol Metab 1997;82:3633-6.

14 Diav-Citrin O, Ornoy A. Teratogen update: antithyroid drugsmethimazole, carbimazole, and propylthiouracil. Teratology 2002;65: $38-44$

15 Azizi F, Khoshniat M, Bahrainian M, Hedayati M. Thyroid function and intellectual development of infants nursed by mothers taking methimazole. J Clin Endocrinol Metab 2000;85:3233-8.

16 Momotani N, Yamashita R, Makino F, Noh JY, Ishikawa N, Ito K. Thyroid function in wholly breast-feeding infants whose mothers take high doses function in wholly breast-feeding infants whose mother

17 Holm LE, Lundell G, Dahlqvist I, Israelsson A. Cure rate after ${ }^{131}$ I therapy for hyperthyroidism. Acta Radiol Oncol 1981;20:161-6.

18 Nygaard B, Hegedus L, Ulriksen P, Nielsen KG, Hansen JM. Radioiodine therapy for multinodular toxic goiter. Arch Intern Med 1999;159:1364-8.

19 Bonnema SJ, Bartalena L, Toft AD, Hegedus L. Controversies in radioiodine therapy: relation to ophthalmopathy, the possible radioprotective effect of antithyroid drugs, and use in large goitres. Eur I Endocrinol 2002;147:1-11.

20 Bartalena L, Marcocci C, Bogazzi F, Manetti L, Tanda ML, Dell'Unto E, et al. Relation between therapy for hyperthyroidism and the course of Graves' ophthalmopathy. N Engl J Med 1998;338:73-8.

21 Palit TK, Miller CC 3rd, Miltenburg DM. The efficacy of thyroidectomy for Graves' disease: A meta-analysis. J Surg Res 2000;90:161-5.

22 Surks MI, Ortiz E, Daniels GH, Sawin CT, Col NF, Cobin RH, et al. Subclinical thyroid disease: scientific review and guidelines for diagnosis and management. JAMA 2004;29:228-38.

23 Gharib H, Tuttle RM, Baskin HJ, Fish LH, Singer PA, McDermott MT. Subclinical thyroid dysfunction: a joint statement on management from the American Association of Clinical Endocrinologists, the American Thyroid Association, and the Endocrine Society. J Clin Endocrinol Metab 2005;90:581-5.

24 Papi G, Pearce EN, Braverman LE, Betterle C, Roti E. A clinical and therapeutic approach to thyrotoxicosis with thyroid stimulating hormone therapeutic approach to thyrotoxicosis with thyr
suppression only. Am J Med 2005;118:349-61.

25 Toft AD. Clinical practice: subclinical hyperthyroidism. $N$ Engl J Med 2001;354:512-6.

(Accepted 25 April 2006)

\section{Endpiece}

\section{The art of medicine}

The aim of the art of medicine is health, but its end is the possession of health. Doctors have to know by which means to bring about health, when it is absent, and by which means to preserve it, when it is present.

Galen. On the sects for beginners. Translated by Walzer R, Frede M. Indianapolis: Hackett Publishing, 1985.

Submitted by E Tullo, postgraduate student, history of medicine, University of Newcastle upon Tyne 